\title{
Grassland Bird Responses to Three Edge Types in a Fragmented Mixed- Grass Prairie
}

\section{Réactions des oiseaux de prairie à trois types de bordures dans une prairie mixte fragmentée}

\author{
Maggi S. Sliwinski ${ }^{1}$ and Nicola Koper ${ }^{1}$
}

\begin{abstract}
One possible factor that may have contributed to the decline of grassland bird populations is edge avoidance. In the mixed-grass prairie, habitat fragmentation is often caused by juxtaposition of habitats with vegetation that is structurally similar to prairie, making it difficult to understand why birds avoid habitat edges. We hypothesized that display height or resource-use strategy, i.e., the degree to which a species depends on grassland habitat, might explain variation in sensitivity to habitat edges among different species of grassland birds. To test our hypotheses, we used data on the abundance of grassland birds in native mixed-grass prairie fields in southern Alberta, Canada, from 2000 to 2002. Point counts were conducted up to $4.1 \mathrm{~km}$ from croplands, $2.2 \mathrm{~km}$ from roads, and $1.8 \mathrm{~km}$ from wetlands. We used nonlinear regression models to determine the distance at which relative abundance of 12 bird species changed in response to edge, and linear regression to determine if display height or resource-use strategy explained variation in response to different types of edges. Variation in response to edge was not explained by display height or resource-use strategy. However, six species avoided wetland edges, two avoided roads, and four avoided cropland. Two species of conservation concern, Chestnut-collared Longspurs (Calcarius ornatus) and Sprague's Pipits (Anthus spragueii), declined in abundance by $25 \%$ or more within $1.95 \mathrm{~km}$ and $0.91 \mathrm{~km}$, respectively, of cropland edges. Because Chestnut-collared Longspurs avoided croplands to at least $1.95 \mathrm{~km}$, it will be important to prevent further fragmentation of mixed-grass prairies by agriculture.
\end{abstract}

RÉSUMÉ. L'évitement des bordures est un des facteurs avancés dans le déclin des populations d'oiseaux de prairie. Dans la prairie mixte, la fragmentation d'habitat se présente souvent sous la forme d'une juxtaposition de milieux dont la végétation est structurellement similaire à la prairie, ce qui rend difficile de comprendre pourquoi les oiseaux évitent les bordures d'habitat. Nous avons émis l'hypothèse voulant que la hauteur de parade ou la stratégie d'utilisation des ressources, c'est-à-dire à quel degré une espèce dépend de l'habitat de prairie, expliquerait peut-être la variation de sensibilité aux bordures chez différentes espèces d'oiseaux de prairie. Afin de tester notre hypothèse, nous avons utilisé des données d'abondance des oiseaux de prairie dans des champs de prairie mixte naturelle du sud de l'Alberta, au Canada, de 2000 à 2002. Des dénombrements par points d'écoute ont été effectués jusqu'à 4,1 km de terres cultivées, jusqu'à $2,2 \mathrm{~km}$ de routes et jusqu'à $1,8 \mathrm{~km}$ de milieux humides. Nous avons utilisé la régression non linéaire dans le but de déterminer la distance à laquelle l'abondance relative de 12 espèces d'oiseaux changeait en réaction aux bordures, et la régression linéaire pour établir si la hauteur de parade ou la stratégie d'utilisation des ressources expliquait la variation de réaction selon les différents types de bordure. La variation dans la réaction aux bordures n'a pas été expliquée par la hauteur de parade ni par la stratégie d'utilisation des ressources. Toutefois, six espèces ont évité les bordures avec les milieux humides, deux ont évité celles avec les routes et quatre, celles avec les terres cultivées. L'abondance de deux espèces dont la conservation est préoccupante, le Plectrophane à ventre noir (Calcarius ornatus) et le Pipit de Sprague (Anthus spragueii), a décliné d'au moins $25 \%$ en deçà de $1,95 \mathrm{~km}$ et de $0,91 \mathrm{~km}$ d'une bordure de terre cultivée, respectivement. Étant donné que le plectrophane a évité les terres cultivées par 1,95 km au minimum, il sera important d'empêcher davantage la fragmentation des prairies mixtes par l'agriculture.

Key Words: Chestnut-collared Longspur; edge effects; fragmentation; mixed-grass prairie; nonlinear regression; road ecology; Sprague's Pipit 


\section{INTRODUCTION}

Grassland birds have experienced significant population declines over the past 40 years (Knopf 1994), partly because of habitat loss and degradation (Samson and Knopf 1994, Davis et al. 1999, Askins et al. 2007). Fragmentation is one outcome of habitat loss and can result in significant edge effects such as lower species abundances near edges (Laurance and Yensen 1991, Ewers and Didham 2006). Studies in forests (e.g., Brittingham and Temple 1983, Ewers and Didham 2008) and tallgrass prairies (e.g., Gates and Gysel 1978, Fletcher and Koford 2003, Bollinger and Gavin 2004) suggest that a number of factors may explain the response of songbirds to edges, including predator avoidance, hyperdynamism, i.e., "an increase in the frequency and/or amplitude of population, community, and landscape dynamics in fragmented habitats" (Laurance 2002:595), and an innate response to edge habitat (Winter et al. 2000, Bollinger and Gavin 2004, Ewers and Didham 2008).

Although the reasons for lower densities of species near anthropogenic edges are intuitive for forests and tallgrass prairies, this is not the case with mixed-grass prairie habitats. For example, forests that are fragmented by agriculture are adjacent to a shorter, more exposed matrix that is inhospitable to forest species (Brittingham and Temple 1983). Conversely, tallgrass prairies may be fragmented by encroaching forests that present a barrier to movement by birds among tallgrassprairie fragments (Fletcher and Koford 2003). In contrast, mixed-grass prairies are fragmented by juxtaposition to habitats that are structurally similar, including some that can provide suitable nesting habitat. For example, a wheat or canola cropland matrix surrounding mixed-grass prairie may not increase predation risk near edges (Davis et al. 2006, Koper and Schmiegelow 2007, but see Horn et al. 2005), and does not create a physical barrier to avian movement among mixedgrass fragments (Davis 2004, Renfrew et al. 2005). Therefore, it is less obvious why mixed-grass prairie birds avoid habitat edges.

Nonetheless, many mixed-grass prairie birds have lower abundances near habitat edges. Sprague's Pipits (Anthus spragueii), Baird's Sparrows (Ammodramus bairdii), and Chestnut-collared Longspurs (Calcaruis ornatus) were shown to avoid habitat edges (Koper and Schmiegelow 2006a, Koper et al. 2009). Davis (2004) showed that the ratio of area to edge explained the abundance of many species better than habitat area alone, signifying that edge avoidance might influence area sensitivity. This suggests that edge habitat can have a negative impact on songbird abundance in mixed-grass prairies, but the mechanisms behind these edge effects are unknown. We used an existing dataset that included crop/ forage, road, and wetland edge types to examine a number of possible mechanisms and hypotheses.
The mechanisms proposed in the literature that might explain edge avoidance include (1) avoiding competition with dominant sympatric species, (2) changes in vegetation structure with distance to edge, (3) variability in microclimate near edges, (4) changes in food availability near edges, (5) avoidance of brood parasites or predators, and (6) an innate preference for preferred habitat types (Bollinger and Gavin 2004). Other possibilities include (7) passive displacement of circular territories near edges (Fletcher and Koford 2003), and (8) avoidance of invasive species that occur near edges (Gelbard and Harrison 2003). Although one or more of these hypotheses might explain edge avoidance, it seems unlikely that some, such as passive displacement, could explain edge avoidance up to and even beyond $1 \mathrm{~km}$ (i.e., Cunningham and Johnson 2006, Koper et al. 2009). Further, it is unclear why some of these mechanisms, such as changes in food availability, would have different effects on different species.

Species-specific behaviors might explain why some species respond to landscape-scale habitat characteristics and others do not (Ewers and Didham 2006). For example, the absence of perches in open grasslands is presumably responsible for the development of divergent territorial displays exhibited by grassland birds. One consequence of this is that species with displays at greater heights can observe more of their surrounding habitat and landscape. This may make them more likely to avoid edge habitats when making third-order habitat selection decisions, i.e., selecting habitat within the home range (Johnson 1980, Koper et al. 2009). We developed this hypothesis following our observation that the Sprague's Pipit display is the highest among mixed-grass obligate birds, and pipits consistently show strong avoidance of habitat edges (Davis et al. 2006, Koper et al. 2009).

A second species-specific characteristic that might alter edge sensitivity is resource-use strategy. Because generalist species have more flexible habitat requirements than specialists, they may be less sensitive to edges. We hypothesize that Sprague's Pipits and Baird's Sparrows, grassland habitat specialists (Robbins and Dale 1999, Ahlering et al. 2009) might be more sensitive to habitat edges than Savannah Sparrows (Passerculus sandwichensis) and Horned Larks (Eremophila alpestris), which are habitat generalists found in both native and non-native landscapes (Beason 1995, Wheelright and Rising 2008).

Further, mechanisms that explain edge avoidance might vary by type of edge. Agricultural edges can create margins dominated by invasive species (Gelbard and Harrison 2003). Agricultural field runoff can be laden with pesticides (Gelbard and Harrison 2003), and there may be reduced food availability in agricultural fields (Hickman et al. 2006). Such reductions in habitat quality near an agricultural matrix can force 
displacement or expansion of territories, resulting in lower abundances near crop edges (Fletcher and Koford 2003).

Mechanisms that might explain road edge avoidance differ from those for crop edges. Roads are structurally dissimilar from mixed-grass prairie, and can be detrimental to some bird species because of increased mortality or the presence of invasive species (Forman and Alexander 1998, Sutter et al. 2000, Gelbard and Harrison 2003). Fences near road edges may allow Brown-headed Cowbirds (Molothrus ater), a brood parasite, greater success at finding nests. Further, avian and mammalian predators may have greater access to grasslands along roads (Johnson and Temple 1990, Winter et al. 2000), as well as fences, because ranchers often create trails along fences when repairing breaks, and cattle often follow fences when dispersing, also creating trails. Roads may cause additional problems for birds because of increased disturbance from vehicular traffic, runoff, and changes in water-flow patterns (Forman and Alexander 1998).

Effects of wetland edges on birds might differ from effects of roads and croplands because wetlands are a natural part of the mixed-grass prairie ecosystem (Dodds et al. 2004). We hypothesize that evolutionary history has allowed birds to develop consistent and predictable responses to wetland edges in that each species should exhibit a response to wetland edges. Cumulatively, these hypotheses suggest that mixed-grass prairie birds should respond to edges, but they might respond differently to different edge types based on the mechanism causing edge avoidance or attraction.

Understanding the mechanisms that influence edge avoidance in mixed-grass prairies may help promote appropriate conservation strategies for birds. Because the mechanisms are poorly understood, we used an existing dataset to examine our hypotheses. We first determined the distances at which all focal species responded to road, wetland, and cropland or forage edges using linear and nonlinear models, and then compared these distances relative to edge type, display height, and resource-use strategy. We hypothesized more species would respond, either positively or negatively, to wetland edges than to cropland or road edges because of long-term exposure. Second, we hypothesized that species with higher displays, and therefore with a better view of their surrounding habitat, would exhibit edge avoidance to a greater distance than species with lower displays. Finally, we hypothesized that mixed-grass prairie specialists would avoid edges more strongly than habitat generalists. These patterns were then used to evaluate the likelihood that avian responses to edge were driven by avian resource-use strategy, passive displacement, and other mechanistic hypotheses.

\section{METHODS}

\section{Study site}

We collected data from 2000 through 2002 in 34 fields in southern Alberta, Canada, within an area $111 \mathrm{~km}(\mathrm{NS}) \mathrm{x} 125$ km (EW; 50 32' 03"; $\left.111^{\circ} 54^{\prime} 57^{\prime \prime}\right)$. Fields were flat or very slightly rolling, and consisted of native mixed-grass prairie that also included wetland basins. Habitat was dominated by the grasses Hesperostipa comata and Bouteloua gracilis interspersed with Opuntia polyacantha, Escobaria vivpara, and Artemisia cana (Guyn and Clark 1999). The three most common edge types bordering grasslands were cropland or forage (hay), roads, and fences (Fig. 1), or wetlands. Croplands were most commonly wheat or canola, with annual variations due to crop rotations. Hayfields were all seeded to tame varieties of forage. Basins contained water throughout the year, but water levels generally declined between April and August. Wetland fringes consisted predominantly of Typha latifolia, Eleocharis palustris, or Scirpus acutus.

Fig. 1. Example of a road/fenced edge in our study area, southern Alberta, Canada. Photo credit: Lalenia Neufeld, 2002.

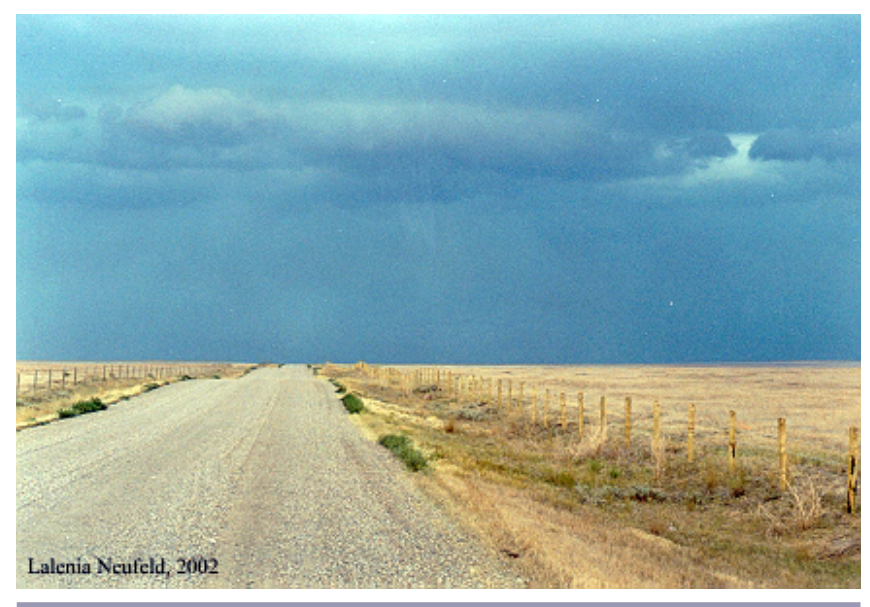

Most roads were gravel and had light traffic. A few roads were paved, and most roads had grassland on both sides. Where fences were present, they consisted of 3-5 strand barbed wire strung between wood or metal fence posts. Approximately 2/3 of the roads had fences on either side, while remaining roads were unfenced. Most roads were adjacent to shallow ditches. There were a few two-track trails that were used for livestock and energy infrastructure management occasionally (once a week to once a day, or less), and we did not consider these to fragment the landscape. Gas well density ranged from 0 to 15 wells/mile ${ }^{2}$. Almost all cropland edges were fenced, but wetlands were unfenced. A few shrubs, i.e., Artemisia cana, were present at low densities, generally covering approximately $0-5 \%$ of the surface area of each plot. Raptors and Brown-headed Cowbirds occasionally used utility lines as perch sites, but this was uncommon because the abundance of utility lines was low within our study area.

We sampled 24 sites in 2000 and 34 sites in 2001 and 2002 (263-278 point-count stations for each year and edge type). Sites ranged in size from 11 to 3239 ha, as defined by roads 
and usually fences along their perimeters. Most sites (94\%) were located in grassland patches $\geq 55962 \mathrm{ha}$, and so were subdivisions of a much larger grassland patch. This suggests that edge effects were independent of patch size because all patches were very large (Koper et al. 2009). Sites had different grazing regimes, including idle (no cattle grazing), deferred grazing (no grazing until after 15 July), or early-season grazing (grazed from 31 May to 15 July). However, stocking rates were low on our study sites (mean $=0.38 \pm 0.35$ [SD] AUM/ ha), which may explain why previous analyses revealed little effect of grazing regime on species densities (Koper and Schmiegelow 2006a). Therefore, we did not include grazing regime as an independent variable in our analyses (see Koper and Schmiegelow $2006 a$ for further details).

\section{Previous use of dataset}

The data used to test our hypotheses were collected in 2000-2002, as part of the second author's PhD research. These data have been used in three previous publications, which differ from the present paper for several reasons. Koper and Schmiegelow (2006a) focused on effects of cattle grazing on ducks and passerines, and Koper and Schmiegelow (2006b) addressed the spatial scale at which different species responded to landscape structure. In neither of these papers did we conduct nonlinear analyses of effects of edge on relative abundance, and we did not determine the distances at which these species responded to edges. Koper et al. (2009) determined the distance at which Sprague's Pipits responded to habitat edges, but we did not determine effects of edge on other species, and thus could not evaluate community-wide trends in responses to edge, and could not explore why different species respond differently to edges. We did not test the hypotheses about why grassland songbirds respond to habitat edges, as proposed in this paper, in these previous publications.

\section{Field methods}

We surveyed breeding birds using point-count plots (5 min, $100-\mathrm{m}$ radius). Point counts were conducted between sunrise and 10:00 (CST) on days with minimal wind $(<20 \mathrm{~km} / \mathrm{hr})$ and little or no precipitation. Each plot was sampled three to five times annually between 20 May and 5 July. Visits were rotated between observers, and visit order was reversed and then alternated to account for variability in detection between early morning and late morning to avoid bias in detection near edges. Unadjusted point counts were averaged over all visits and years to account for variability among and within years. Shorebirds were only counted once if we could not determine that the bird was a different individual because shorebirds had a tendency to follow observers during point-count surveys (M. Sliwinski, N. Koper personal observation). Vegetation structure was also surveyed, and is discussed briefly (see Koper and Schmiegelow $2006 a$ for further details).

Samples were stratified by distance to wetlands and roads/ fences (hereafter roads; Johnson 1999) by locating plots at 300-m intervals along transects radiating from wetlands or roads. Plots were not formally stratified by distance to cropland or hayfields because we did not initially expect to explore this variable when we designed the study in 2000, but instead were randomly located relative to distance to cropland or hayfield. Depending on field size, we had 1 to 20 upland plots per field. Centers of plots were located 100 to $1855 \mathrm{~m}$ from wetlands, 100 to $4127 \mathrm{~m}$ from cropland/hayfields, and 100 to $2250 \mathrm{~m}$ from roads.

We used the relative abundance of the 12 bird species for which we had sufficient data for analyses, including Baird's Sparrow, Brown-headed Cowbird, Chestnut-collared Longspur, Claycolored Sparrow (Spizella pallida), Horned Lark, Long-billed Curlew (Numenius americanus), Marbled Godwit (Limosa fedoa), Savannah Sparrow, Sprague's Pipit, Vesper Sparrow (Pooecetes gramineus), Western Meadowlark (Sturnella neglecta), and Willet (Tringa semipalmata). Each species was found in at least $15 \%$ of plots sampled, except Long-billed Curlews (6\% of plots sampled). Nine species are passerines and three are shorebirds; six species are grassland specialists and six are generalists, while one (Brown-headed Cowbird) is an obligate brood parasite (Table 1). Specialist and generalist categorizations were determined using Mengel (1970), except for Willet, which we considered a wetland/upland specialist (Koper and Schmiegelow 2006a).

\section{Statistical analysis}

We used unadjusted counts of birds within $100 \mathrm{~m}$ of observers as an index of relative abundance (Johnson 2008). This was the most appropriate index of relative abundance because (1) we minimized effects of observer bias in the field instead of statistically; (2) most of our focal species have loud vocalizations and courtship displays readily detectable up to $200 \mathrm{~m}$ or more, so it was reasonable to assume that detectability of singing or calling individuals within $100 \mathrm{~m}$ was high; (3) obstruction by tall vegetation is usually unproblematic in mixed-grass prairies and most vegetation in our study area was $<0.5 \mathrm{~m}$ high; (4) previous analyses of detection functions by distance to observer demonstrated that the assumption of maximal detection at the center of the point count is violated for most of these species and thus distance sampling is inappropriate (R. Fisher, personal communication); and (5) distance sampling assumptions are difficult to meet in the field (Efford and Dawson 2009). As such, we believe the unadjusted counts were the best index of relative abundance, but recognize they are not a measure of density or population size.

Because we were analyzing point-count data, we assumed a Poisson distribution for the residuals of all species' relative abundances; suitability of this model was evaluated using the $\mathrm{c}^{2} / \mathrm{df}$ ratio. Relative abundances of Horned Larks and Chestnut-collared Longspurs were analyzed using a normal distribution, because the Poisson did not fit well and diagnostic graphs demonstrated that the normal distribution was appropriate. 
Table 1. Summary of species characteristics of focal bird species used to evaluate edge effects.

\begin{tabular}{|c|c|c|c|c|c|c|}
\hline Species & Guild & $\begin{array}{l}\text { Resource-use } \\
\text { strategy }^{\dagger}\end{array}$ & Habitat preference & Display height (m) & $\begin{array}{l}\text { Average territory } \\
\text { size (ha) }\end{array}$ & References \\
\hline $\begin{array}{l}\text { Baird's Sparrow } \\
\text { (Ammodramus } \\
\text { bairdii) }\end{array}$ & Songbird & Specialist & $\begin{array}{l}\text { Mixed-grass } \\
\text { endemic }\end{array}$ & $2-3$ & 1.5 & $\begin{array}{c}\text { Green 1992, Cartwright et al. } \\
1937\end{array}$ \\
\hline $\begin{array}{l}\text { Brown-headed } \\
\text { Cowbird } \\
\text { (Molothrus ater) }\end{array}$ & $\begin{array}{l}\text { Nest } \\
\text { parasite }\end{array}$ & Generalist & $\begin{array}{l}\text { Open habitat near } \\
\text { edges }\end{array}$ & $\begin{array}{l}\text { 0-highest available } \\
\text { perch }\end{array}$ & Up to 400 & Lowther 1993 \\
\hline $\begin{array}{l}\text { Chestnut-collared } \\
\text { Longspur } \\
\text { (Calcarius ornatus) }\end{array}$ & Songbird & Specialist & $\begin{array}{l}\text { Mixed-grass } \\
\text { endemic }\end{array}$ & $10-15$ & 0.6 & Hill and Gould 1997 \\
\hline $\begin{array}{l}\text { Clay-colored } \\
\text { Sparrow } \\
\text { (Spizella pallida) }\end{array}$ & Songbird & Generalist & Shrub-grassland & $0.5-3$ & 0.25 & $\begin{array}{c}\text { Knapton } 1994 \text {, Vickery et al. } \\
1999\end{array}$ \\
\hline $\begin{array}{l}\text { Horned Lark } \\
\text { (Eremophila } \\
\text { alpestris) }\end{array}$ & Songbird & Generalist & $\begin{array}{l}\text { Short, sparsely } \\
\text { vegetated }\end{array}$ & $\begin{array}{l}\text { 80-250 (flight song), } \\
0 \text { (ground song) }\end{array}$ & 2.0 & Beason 1995 \\
\hline $\begin{array}{l}\text { Long-billed Curlew } \\
\text { (Numenius } \\
\text { americanus) }\end{array}$ & Shorebird & Specialist & $\begin{array}{l}\text { Short- and mixed- } \\
\text { grass prairie }\end{array}$ & $10-15$ & 14 & $\begin{array}{l}\text { Allen 1980, Dugger and Dugger } \\
2002\end{array}$ \\
\hline $\begin{array}{l}\text { Marbled Godwit } \\
\text { (Limosa fedoa) }\end{array}$ & Shorebird & Specialist & $\begin{array}{l}\text { Short- and mixed- } \\
\text { grass near wetlands }\end{array}$ & 90 & 90 & $\begin{array}{c}\text { Nowicki 1973, Gratto-Trevor } \\
2000\end{array}$ \\
\hline $\begin{array}{l}\text { Savannah Sparrow } \\
\text { (Passerculus } \\
\text { sandwichensis) }\end{array}$ & Songbird & Generalist & Mixed-grass prairie & $0-8$ & 0.5 & Wheelwright and Rising 2008 \\
\hline $\begin{array}{l}\text { Sprague's Pipit } \\
\text { (Anthus spragueii) }\end{array}$ & Songbird & Specialist & $\begin{array}{l}\text { Mixed-grass } \\
\text { endemic }\end{array}$ & $50-100$ & 1.2 & $\begin{array}{l}\text { Robbins 1998, Fisher and Davis } \\
2011\end{array}$ \\
\hline $\begin{array}{l}\text { Vesper Sparrow } \\
\text { (Pooecetes } \\
\text { gramineus) }\end{array}$ & Songbird & Generalist & $\begin{array}{l}\text { Dry fields with } \\
\text { shrubs }\end{array}$ & $25-75$ & 4.2 & $\begin{array}{c}\text { Wells and Vickery 1994, Jones } \\
\text { and Cornely } 2002\end{array}$ \\
\hline $\begin{array}{l}\text { Western Meadowlark } \\
\text { (Sturnella neglecta) }\end{array}$ & Songbird & Generalist & Open country & $\begin{array}{l}\text { 0-highest available } \\
\text { perch }\end{array}$ & 7 & Davis and Lanyon 2008 \\
\hline $\begin{array}{l}\text { Willet } \\
\text { (Tringa semipalmata) }\end{array}$ & Shorebird & Specialist & Open with wetlands & $<250$ & 44 & $\begin{array}{l}\text { Lowther et al. 2001; M. Ryan, } \\
\text { personal communication }\end{array}$ \\
\hline
\end{tabular}

Extent to which species depends on grasslands, from Mengel (1970), except for Willet (Koper and Schmiegelow 2006a).

For each bird species, nonlinear mixed models were developed in SAS software 9.2 (SAS Institute 2008) using PROC NLMIXED for those species with a Poisson distribution, and PROC MODEL or PROC NLMIXED for those with a normal distribution, to describe the relationship between distance to edge and relative abundance of each species. Nonlinear models were used to help us detect the existence of asymptotes, which allowed us to estimate the distance where edges were influential. The fit of seven different models was compared using Akaike's Information Criterion (AIC) because the ratio of point-count plots to independent variables exceeded 40:1 (Burnham and Anderson 2002), and the best-fitting model was selected for evaluating response of each bird species to distance to edge (Koper et al. 2009). The models evaluated included the null model (relative abundance = intercept), which fit best if there was no detectable response to edge, the linear model (relative abundance $=$ intercept + distance to edge), the quadratic model (relative abundance $=$ intercept + distance to edge + distance to edge ${ }^{2}$ ), the cubic model (relative abundance $=$ intercept + distance to edge + distance to edge ${ }^{2}$
+ distance to edge ${ }^{3}$ ), the quartic model (relative abundance $=$ intercept + distance to edge + distance to edge ${ }^{2}+$ distance to edge $^{3}+$ distance to edge $e^{4}$, the exponential model (relative abundance $\left.=T^{\prime} e^{\left(B^{\prime} \text { distance }\right)}\right)$, and the logistic model (relative abundance $=T /\left(1+u^{\prime}\right.$ distance $\left.^{B}\right)$, where $T$ is the asymptote, $u$ defines the location of the curve, and $B$ the shape of the curve. Because AIC is biased toward overly complex models (Quinn and Keough 2002), we also report those cases where the null model had a $\triangle \mathrm{AIC}$ value $<2$, indicating that the null model fit the data almost as well as the more complex model; we acknowledge there may be no effect of distance to edge in these cases, but we still based our inferences on the best-fitting model. The above models were applied three times for each of our focal species to evaluate the effects of distance to cropland, distance to road, and distance to wetland. Including patch identification as a random variable did not alter our results so it was not included in the final models (Koper et al. 2009). For Chestnut-collared Longspurs, only the null model and the linear model converged successfully for the crop-edge analysis. A potentially influential outlier was detected in the 
data for the response of Baird's Sparrows to roads; these models were run twice, once with the outlier and once without it, and results were the same for both.

Results of the modeling process were used to determine the distance threshold at which species abundance changed by $25 \%$ in response to an edge (Koper et al. 2009). Although arbitrary, the threshold of $25 \%$ was chosen because this presumably represents a biologically significant change in relative abundance. This value is theoretically consistent with the use of EC25 in ecotoxicology, or the effective concentration at which a $25 \%$ decline in the response variable is detected. This has been used as a "probable-no-effect" concentration in ecotoxicology because "more severe effect levels (e.g., 50\%) were considered too great an impact, and lower levels (e.g., 10\%) can only rarely be shown to be different statistically from controls" (Sheppard et al. 2005:115). Thus, theoretically the interpretation is that there is no detectable effect when there is less than $25 \%$ change in relative abundance. We caution, however, that the absence of a detectable effect does not mean there is no effect, and the level at which an effect is detectable will vary among species. Thus, we reiterate that the threshold of $25 \%$, although biologically and statistically reasonable, is arbitrary.

To calculate $25 \%$ change when a species' relative abundance increased as distance to edge increased, the maximum abundance (farthest from the edge) was multiplied by 0.75 . The result was the distance at which relative abundance decreased by $25 \%$. If a species' relative abundance decreased as distance to edge increased, the minimum abundance (farthest from the edge), was multiplied by 1.25 to determine the distance at which abundance increased by $25 \%$. If a species' abundance reached an asymptote, e.g., exponential or logistic model, then the calculated value for edge effects is a good estimate of the distance at which the relative abundance changed by $25 \%$. However, if the response did not reach an asymptote, then our approach underestimated the distance to edge at which the abundance of these species changed, although the relative order of species' responses to edge should be estimated correctly. As such, our estimates of the effect of species' characteristics (display height and resource-use strategy) on responses to distance to edge should be robust, whereas our estimates of the actual distance to edge at which species' abundance changed were underestimated in some cases. Reflected confidence intervals were calculated for distance at maximum abundance and distance at $25 \%$ change (Slud et al. 1984). Many of these confidence intervals include an undefined term because a value cannot be calculated beyond the range of distances at which we collected data, i.e., $<0 \mathrm{~km}$ and greater than the greatest distance from edge that was sampled).

A linear regression analysis was used to determine the relationship between display height and the distance at which each species responded to habitat edge. We modeled the relationship between average display height $(\mathrm{m})$ of each species and the distance $(\mathrm{km})$ at which there was a $25 \%$ change in relative abundance of that species (PROC REG, SAS Software 9.2, SAS Institute 2008). Analyses were conducted for each of the three edge types. Finally, we ran a $c^{2}$ analysis to determine if specialist species responded more, either positively or negatively, to edges than generalist species. We pooled data from the three edge types to achieve the requirement that no cell include fewer than five observations (Quinn and Keough 2002). Values are presented as means \pm 1 SD.

\section{RESULTS}

\section{Distance to crop edge}

Edge avoidance was detected up to $1.95 \mathrm{~km}$ from crop edges by Chestnut-collared Longspurs (average edge avoidance $=$ $0.91 \pm 0.80 \mathrm{~km}$, maximum possible $=4.1 \mathrm{~km}$; Fig. 2). Four species, Chestnut-collared Longspur, Horned Lark, Savannah Sparrow, and Sprague's Pipit, increased in abundance as distance to crop edge increased, and two species, Clay-colored Sparrow and Western Meadowlark, decreased in abundance (Table 2). Baird's Sparrows exhibited a spatially nonlinear response and neither consistently avoided nor were attracted to crop edge. Brown-headed Cowbirds, Long-billed Curlews, Marbled Godwits, Vesper Sparrows, and Willets did not have a detectable response to distance to cropland (Table 2). Claycolored Sparrows and Western Meadowlarks declined continuously in abundance with increasing distance from crops, suggesting the decline may continue beyond the range of distances sampled (Table 2). Although Savannah Sparrow abundance decreased and Western Meadowlark abundance increased in response to crop edges, the null models for these two species had DAIC $<2$ and may indicate that they in fact did not respond to edges (Arnold 2010).

\section{Distance to roads}

Edge avoidance was detected at distances up to $0.8 \mathrm{~km}$ from roads by Baird's Sparrows (average $=0.30 \pm 0.28 \mathrm{~km}$, maximum possible $=2.2 \mathrm{~km}$ ), but this is an underestimate because the response did not reach an asymptote. Abundance of seven species did not display a detectable response to distance to roads (Table 3). However, two species, Baird's Sparrows and Marbled Godwits, increased in abundance with distance to roads and two species, Brown-headed Cowbirds and Vesper Sparrows, decreased; Clay-colored Sparrows had a nonlinear response, but generally declined with distance to roads (Table 3). None of the species' response curves reached an asymptote. Relative abundance of Clay-colored Sparrows began to decline $\sim 0.1 \mathrm{~km}$ from roads. Although Vesper Sparrows were attracted to road edges, the null model for this species had DAIC $<2$, suggesting there may have been no response to roads. 
Table 2. Effect of distance to cropland/forage on 12 bird species in Alberta, Canada, 2000-2002.

\begin{tabular}{|c|c|c|c|c|c|c|c|}
\hline$\overline{\text { Species }}$ & $\begin{array}{l}\text { Avoidance/ } \\
\text { Attraction }\end{array}$ & $\begin{array}{l}\text { Asymptote } \\
\text { reached? }\end{array}$ & $\begin{array}{l}\text { Distance at maximum } \\
\text { abundance }(\mathrm{CI})(\mathrm{km})\end{array}$ & $\begin{array}{l}\text { Distance at } 25 \% \\
\text { change }(\mathrm{CI})(\mathrm{km})\end{array}$ & $\begin{array}{c}\text { Selected } \\
\text { model }\end{array}$ & $\begin{array}{l}\text { DAIC from } \\
\text { null model }\end{array}$ & AIC weight \\
\hline $\begin{array}{l}\text { Baird's Sparrow } \\
\text { (Ammodramus bairdii) }\end{array}$ & Neither & No & & & Quadratic & -5.3 & 0.69 \\
\hline $\begin{array}{l}\text { Brown-headed } \\
\text { Cowbird } \\
\text { (Molothrus ater) }\end{array}$ & None $^{\dagger}$ & & & & Null & 0 & 0.71 \\
\hline $\begin{array}{l}\text { Chestnut-collared } \\
\text { Longspur } \\
\text { (Calcarius ornatus) }\end{array}$ & Avoided & No & $\begin{array}{c}2.97 \\
(2.49 \text {-und. })\end{array}$ & $\begin{array}{c}1.95 \\
(1.68-2.22)\end{array}$ & Linear & -63.0 & 0.55 \\
\hline $\begin{array}{l}\text { Clay-colored Sparrow } \\
\text { (Spizella pallida) }\end{array}$ & Attracted & No & $\begin{array}{c}0 \\
\text { (und.-0.20) }\end{array}$ & $\begin{array}{c}2.79 \\
\text { (2.34-und.) }\end{array}$ & Linear & -8.5 & 0.58 \\
\hline $\begin{array}{l}\text { Horned Lark } \\
\text { (Eremophila alpestris) }\end{array}$ & Avoided & No & $\begin{array}{c}2.97 \\
\text { (1.16-und.) }\end{array}$ & $\begin{array}{c}0.79 \\
(0.08-1.51)\end{array}$ & Linear & -3.1 & 0.25 \\
\hline $\begin{array}{l}\text { Long-billed Curlew } \\
\text { (Numenius } \\
\text { americanus) }\end{array}$ & None & & & & Null & 0 & 0.29 \\
\hline $\begin{array}{l}\text { Marbled Godwit } \\
\text { (Limosa fedoa) }\end{array}$ & None & & & & Null & 0 & 0.65 \\
\hline $\begin{array}{l}\text { Savannah Sparrow } \\
\text { (Passerculus } \\
\text { sandwichensis) }\end{array}$ & Avoided & No & $\begin{array}{c}2.97 \\
\text { (0.75-und.) }\end{array}$ & $\begin{array}{c}0 \\
\text { (und.-1.27) }\end{array}$ & Linear & -0.7 & 0.40 \\
\hline $\begin{array}{l}\text { Sprague's Pipit } \\
\text { (Anthus spragueii) }\end{array}$ & Avoided & Yes & $\begin{array}{c}2.97 \\
\text { (2.54-und.) }\end{array}$ & $\begin{array}{c}0.91 \\
(0.66-1.30)\end{array}$ & Expon. ${ }^{\S}$ & -19.0 & 0.81 \\
\hline $\begin{array}{l}\text { Vesper Sparrow } \\
\text { (Pooecetes gramineus) }\end{array}$ & None & & & & Null & 0 & 0.53 \\
\hline $\begin{array}{l}\text { Western Meadowlark } \\
\text { (Sturnella neglecta) }\end{array}$ & Attracted & No & $\begin{array}{c}0 \\
\text { (und.-1.22) }\end{array}$ & $\begin{array}{c}0.65 \\
(0.20-1.34)\end{array}$ & Expon. & -1.4 & 0.37 \\
\hline $\begin{array}{l}\text { Willet } \\
\text { (Tringa semipalmata) }\end{array}$ & None & & & & Null & 0 & 0.37 \\
\hline
\end{tabular}

"Neither" was used to indicate that there was no clear pattern of avoidance or attraction for the species; "none" was used to indicate that the best-fitting model was null.

${ }^{\ddagger}$ Und. = undefined.

${ }^{\S}$ Expon. = exponential.

Fig. 2. Effect of distance to cropland/forage on Chestnutcollared Longspur (Calcarius ornatus) relative abundance in southern Alberta, Canada, 2000-2002. Figure produced using R graphing software (R Core Team 2012).

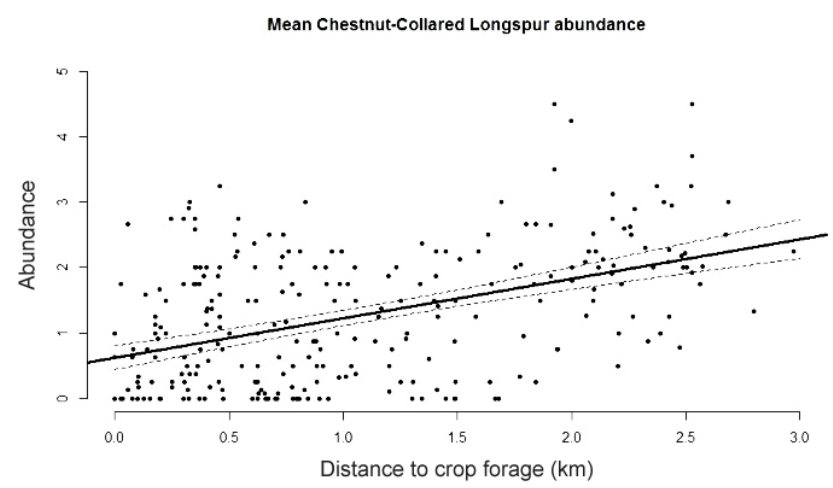

\section{Distance to wetland edge}

Edge avoidance was detected up to $1.05 \mathrm{~km}$ from wetlands by Chestnut-collared Longspurs (average $=0.75 \pm 0.34 \mathrm{~km}$, maximum possible $=1.8 \mathrm{~km}$ ). Six species, Baird's Sparrow, Chestnut-collared Longspur, Horned Lark, Long-billed Curlew, Marbled Godwit, and Sprague's Pipit, increased in abundance with distance to wetland, and five, Brown-headed Cowbird, Clay-colored Sparrow, Savannah Sparrow, Western Meadowlark, and Willet, decreased (Table 4). The response of Vesper Sparrows to distance to wetland was nonlinear. Most species that selected for wetland edges declined in abundance continuously with distance to wetlands, except Savannah Sparrows, suggesting that we underestimated the distances at which most species responded to wetland edge. Although Marbled Godwit abundance increased and Willet abundance decreased with distance to wetland edge, the null models for these two species had DAIC < 2, suggesting that there may have been no effect of edge on species' abundance.

\section{Display height and resource-use strategy}

Variation in response to edges (cropland/forage, roads, and wetlands) was not explained by display height for any edge 
Table 3. Effect of distance to roads on 12 bird species in Alberta, Canada, 2000-2002.

\begin{tabular}{|c|c|c|c|c|c|c|c|}
\hline Species & $\begin{array}{l}\text { Avoidance/ } \\
\text { Attraction }\end{array}$ & $\begin{array}{l}\text { Asymptote } \\
\text { reached? }\end{array}$ & $\begin{array}{l}\text { Distance at maximum } \\
\text { abundance }(\mathrm{CI})(\mathrm{km})\end{array}$ & $\begin{array}{c}\text { Distance at } 25 \% \\
\text { change }(\mathrm{CI}) \\
(\mathrm{km})\end{array}$ & $\begin{array}{c}\text { Selected } \\
\text { model }\end{array}$ & $\begin{array}{l}\text { DAIC from } \\
\text { null model }\end{array}$ & AIC weight \\
\hline $\begin{array}{l}\text { Baird's Sparrow } \\
\text { (Ammodramus bairdii) }\end{array}$ & Avoided & No & $\begin{array}{c}0.8 \\
\left(0.45 \text {-und. }{ }^{\dagger}\right)\end{array}$ & $\begin{array}{c}0.5 \\
\text { (0.30-und.) }\end{array}$ & Quadratic & -8.3 & 0.27 \\
\hline $\begin{array}{l}\text { Brown-headed } \\
\text { Cowbird } \\
\text { (Molothrus ater) }\end{array}$ & Attracted & No & $\begin{array}{c}0 \\
\text { (und.--0.43) }\end{array}$ & $\begin{array}{c}1.0 \\
(0.70-1.37)\end{array}$ & Linear & -6.8 & 0.33 \\
\hline $\begin{array}{l}\text { Chestnut-collared } \\
\text { Longspur } \\
\text { (Calcarius ornatus) }\end{array}$ & None & & & & Null & 0 & 0.31 \\
\hline $\begin{array}{l}\text { Clay-colored Sparrow } \\
\text { (Spizella pallida) }\end{array}$ & Neither & No & & & Quartic & -15.0 & 0.75 \\
\hline $\begin{array}{l}\text { Horned Lark } \\
\text { (Eremophila alpestris) }\end{array}$ & None & & & & Null & 0 & 0.26 \\
\hline $\begin{array}{l}\text { Long-billed Curlew } \\
\text { (Numenius } \\
\text { americanus) }\end{array}$ & None & & & & Null & 0 & 0.26 \\
\hline $\begin{array}{l}\text { Marbled Godwit } \\
\text { (Limosa fedoa) }\end{array}$ & Avoided & No & $\begin{array}{c}0.5 \\
\text { (und.--0.83) }\end{array}$ & $\begin{array}{c}0.1 \\
(0.05-0.56)\end{array}$ & Quadratic & -6.2 & 0.45 \\
\hline $\begin{array}{l}\text { Savannah Sparrow } \\
\text { (Passerculus } \\
\text { sandwichensis) }\end{array}$ & None & & & & Null & 0 & 0.36 \\
\hline $\begin{array}{l}\text { Sprague's Pipit } \\
\text { (Anthus spragueii) }\end{array}$ & None & & & & Null & 0 & 0.37 \\
\hline $\begin{array}{l}\text { Vesper Sparrow } \\
\text { (Pooecetes gramineus) }\end{array}$ & Attracted & No & $\begin{array}{c}.025 \\
\text { (und.-0.67) }\end{array}$ & $\begin{array}{c}0.87 \\
(0.48-1.33)\end{array}$ & Linear & -1.5 & 0.28 \\
\hline $\begin{array}{l}\text { Western Meadowlark } \\
\text { (Sturnella neglecta) }\end{array}$ & None & & & & Null & 0 & 0.25 \\
\hline $\begin{array}{l}\text { Willet } \\
\text { (Tringa semipalmata) }\end{array}$ & None & & & & Null & 0 & 0.35 \\
\hline
\end{tabular}

type (crop edge: $R^{2}=0.04, p=0.53$; road edge: $R^{2}=0.01, p$ $=0.72$; wetland edge: $\left.R^{2}=0.08, p=0.39\right)$. Similarly, generalist and specialist species responded equally to the presence of edges $\left(c^{2}=0.0, p=1.0\right)$. However, there were qualitative trends within guilds. Mixed-grass specialists, i.e., Baird's Sparrows, Chestnut-collared Longspurs, and Sprague's Pipits, increased in abundance with distance from cropland and wetland edges, but showed no response to roads, except Baird's Sparrows responded negatively but weakly to roads. Shorebirds, Longbilled Curlews, Marbled Godwits, and Willets, did not respond to cropland edges and all decreased in abundance with distance to wetlands beyond $0.4 \mathrm{~km}$ (Fig. 3). Generalists responded both positively and negatively to different edge types, e.g., Savannah Sparrows avoided crop edges, but were attracted to wetland edges and did not respond to road edges.

\section{DISCUSSION}

Many species responded negatively to different types of habitat edges, and edge avoidance was detected at large distances from edges. Indeed, although the greatest distance at which we detected edge effects was $1.95 \mathrm{~km}$, this maximum distance was limited by our study design, and thus may be an underestimate of the distance at which edges influence grassland birds. Most importantly from a conservation perspective, Sprague's Pipits and Chestnut-collared Longspurs, two threatened species, avoided cropland edges, an increasingly common edge type in the mixed-grass prairies. Further, Baird's Sparrows and Marbled Godwits, two species considered threatened in Canada (COSEWIC 2010) and the USA (U.S. Fish and Wildlife Service 2008), respectively, avoided road edges. Increased fragmentation of mixed-grass prairies by anthropogenic features may have contributed to population declines of these threatened species. We were unable, however, to explain the mechanisms behind this apparent edge avoidance.

In contrast to our first prediction, the distance at which species responded to habitat edge was not correlated with display height, suggesting that the proximate explanation for edge avoidance was not simply the likelihood of detecting habitat edges during aerial displays. Each of these species flies higher than their display height during migration; it is possible that rather than selecting territories relative to distance to edges in 
Table 4. Effect of distance to wetlands on 12 bird species in Alberta, Canada, 2000-2002.

\begin{tabular}{|c|c|c|c|c|c|c|c|}
\hline Species & $\begin{array}{l}\text { Avoidance/ } \\
\text { Attraction }\end{array}$ & $\begin{array}{l}\text { Asymptote } \\
\text { reached? }\end{array}$ & $\begin{array}{l}\text { Distance at maximum } \\
\text { abundance }(\mathrm{CI})(\mathrm{km})\end{array}$ & $\begin{array}{c}\text { Distance at } 25 \% \\
\text { change }(\mathrm{CI}) \\
(\mathrm{km})\end{array}$ & $\begin{array}{c}\text { Selected } \\
\text { model }\end{array}$ & $\begin{array}{l}\text { DAIC from } \\
\text { null model }\end{array}$ & AIC weight \\
\hline $\begin{array}{l}\text { Baird's Sparrow } \\
\text { (Ammodramus bairdii) }\end{array}$ & Avoided & No & $\begin{array}{c}0.9 \\
\left(0.73 \text {-und. }{ }^{\dagger}\right)\end{array}$ & $\begin{array}{c}0.80 \\
\text { (0.69-und.) }\end{array}$ & Quartic & -10.1 & 0.53 \\
\hline $\begin{array}{l}\text { Brown-headed } \\
\text { Cowbird } \\
\text { (Molothrus ater) }\end{array}$ & Attracted & Yes & $\begin{array}{c}0 \\
\text { (und.-0.07) }\end{array}$ & $\begin{array}{c}0.78 \\
\text { (0.62-und.) }\end{array}$ & Quadratic & -81.4 & 0.39 \\
\hline $\begin{array}{l}\text { Chestnut-collared } \\
\text { Longspur } \\
\text { (Calcarius ornatus) }\end{array}$ & Avoided & No & $\begin{array}{c}1.15 \\
\text { (1.0-und.) }\end{array}$ & $\begin{array}{c}1.05 \\
(0.93-1.1)\end{array}$ & Quartic & -72.1 & 0.36 \\
\hline $\begin{array}{l}\text { Clay-colored Sparrow } \\
\text { (Spizella pallida) }\end{array}$ & Attracted & Yes & $\begin{array}{c}0.035 \\
\text { (und.-0.24) }\end{array}$ & $\begin{array}{c}1.15 \\
\text { (1.08-und.) }\end{array}$ & Quartic & -28.1 & 0.46 \\
\hline $\begin{array}{l}\text { Horned Lark } \\
\text { (Eremophila alpestris) }\end{array}$ & Avoided & No & $\begin{array}{c}1.15 \\
\text { (und.-und.) }\end{array}$ & $\begin{array}{c}0.98 \\
\text { (0.05-und.) }\end{array}$ & Cubic & -15.1 & 0.59 \\
\hline $\begin{array}{l}\text { Long-billed Curlew } \\
\text { (Numenius } \\
\text { americanus) }\end{array}$ & Avoided & No & $\begin{array}{c}0.43 \\
\text { (und.-0.45) }\end{array}$ & $\begin{array}{c}0.31 \\
\text { (und.-0.71) }\end{array}$ & Cubic & 5.4 & 0.42 \\
\hline $\begin{array}{l}\text { Marbled Godwit } \\
\text { (Limosa fedoa) }\end{array}$ & Avoided & No & $\begin{array}{c}1.15 \\
\text { (0.70-und.) }\end{array}$ & $\begin{array}{c}1.0 \\
(0.10-1.02)\end{array}$ & Quadratic & -1.5 & 0.31 \\
\hline $\begin{array}{l}\text { Savannah Sparrow } \\
\text { (Passerculus } \\
\text { sandwichensis) }\end{array}$ & Attracted & No & $\begin{array}{c}0 \\
\text { (und.-0.12) }\end{array}$ & $\begin{array}{c}1.08 \\
\text { (0.98-und.) }\end{array}$ & Cubic & -3.1 & 0.35 \\
\hline $\begin{array}{l}\text { Sprague's Pipit } \\
\text { (Anthus spragueii) }\end{array}$ & Avoided & Yes & $\begin{array}{c}1.15 \\
\text { (0.98-und.) }\end{array}$ & $\begin{array}{c}0.35 \\
(0.28-0.46)\end{array}$ & Expon. ${ }^{\ddagger}$ & -82.9 & 0.45 \\
\hline $\begin{array}{l}\text { Vesper Sparrow } \\
\text { (Pooecetes gramineus) }\end{array}$ & Neither ${ }^{\S}$ & No & & & Quartic & -5.0 & 0.72 \\
\hline $\begin{array}{l}\text { Western Meadowlark } \\
\text { (Sturnella neglecta) }\end{array}$ & Attracted & No & $\begin{array}{c}1.15 \\
\text { (0.21-und.) }\end{array}$ & $\begin{array}{c}0.85 \\
(0.61-1.15)\end{array}$ & Linear & -12.5 & 0.42 \\
\hline $\begin{array}{l}\text { Willet } \\
\text { (Tringa semipalmata) }\end{array}$ & Attracted & No & $\begin{array}{c}0 \\
\text { (und.-0.43) }\end{array}$ & $\begin{array}{c}0.94 \\
\text { (0.50-und.) }\end{array}$ & Expon. & -1.9 & 0.33 \\
\hline
\end{tabular}

Und. = undefined.

Expon. = exponential.

$\S$ "Neither" was used to indicate that there was no clear pattern of avoidance or attraction for the species.

the context of third-order habitat selection (Johnson 1980) once on the breeding grounds, that they in fact select territories far from edges in the context of second-order habitat selection, when declining from migration flights each spring.

Our second prediction suggesting that specialists and generalists would respond differently to edges was also refuted. However, we were forced to pool edge types, and to pool the shorebird species with specialists and the shrub species, i.e., Clay-colored Sparrows, with generalists to conduct the required analysis. A qualitative examination of our results suggests a more complex pattern. The abundance of all three prairie-specialist songbird species increased with distance to wetland, and four of the six generalist songbird species decreased with distance to wetland. These responses are consistent with studies suggesting that specialists are influenced more by edges, and generalists are influenced less because of less specific habitat requirements (Ewers and Didham 2006). Willets and Clay-colored Sparrows responded as predicted by showing a preference for wetland edges (Ryan and Renken 1987, Knapton 1994, Dechant et al. 2003a,b). Thus, it is likely that resource-use strategies influence species' responses to edge. However, it is also possible that there is no significant relationship between edge avoidance and resourceuse strategy because the different species are responding to something besides the presence or absence of grassland habitat.

Our results were consistent with our prediction that each species would respond to wetland edges. Our unpublished data suggest this effect was not driven by vegetation structure around wetlands in our study sites, because responses were not consistent with effects of edge on vegetation structure. For example, vegetation density was higher closer to wetlands, increasing by $25 \%$ from the minimum density at $1.0 \mathrm{~km}$ from water $(\mathrm{LCL}=0.98, \mathrm{UCL}=1.08)$; this change in vegetation structure with distance to edge is not consistent with any species' response to wetland edge. Our results differ from a previous study in which there was no response of Western Meadowlark, Baird's Sparrow, and Chestnut-collared Longspur to water, and in which Horned Larks were more abundant near water (Fontaine et al. 2004); however, water developments in their study were not natural wetlands, but rather infrastructure built by landowners to provide water to 
cattle. Grassland birds might respond to anthropogenic water bodies differently than wetlands, because wetlands have been a habitat type present over their evolutionary history. Although it is possible that unmeasured vegetation structure variables might be influential, some species that showed no response to other edge types, e.g., Long-billed Curlew and Brown-headed Cowbird, still responded to wetland edges. This is consistent with our hypothesis that our focal species would respond to edges that were present throughout their evolutionary history, such as wetland edges, and that their response to such edges might reflect habitat selection at a scale greater than that of local vegetation characteristics.

Fig. 3. Response of Long-billed Curlew (Numenius americanus; plot A), Marbled Godwit (Limosa fedoa; plot B), and Willet (Tringa semipalmata; plot C) to wetland edge habitat in southern Alberta, Canada, 2000-2002. Each species' abundance decreased above $0.4 \mathrm{~km}$ from wetlands. Figure produced using R graphing software (R Core Team 2012).
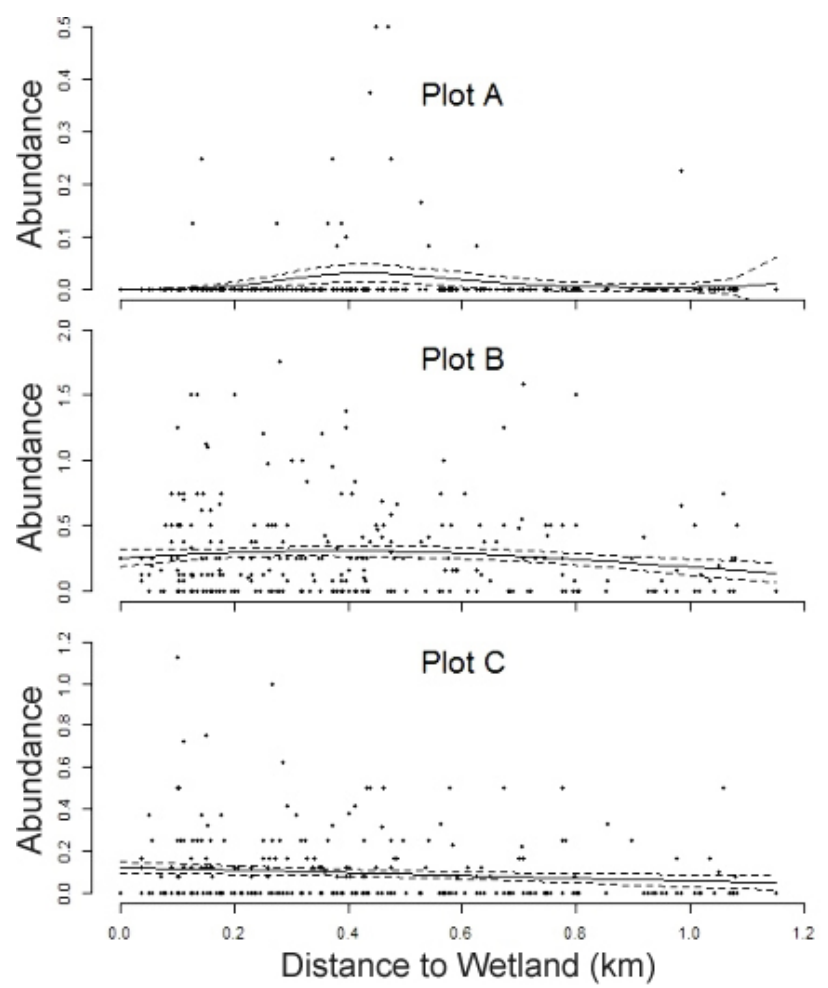

Roads, which have been a landscape feature on the prairies for only a short period, prompted fewer responses to edge from our focal species. Only two species in our study avoided road edges, and they showed less avoidance of roads compared with other edges. In our study, roads may not have been avoided because traffic volumes were low (but see Ingelfinger and Anderson 2004). Further, roads had not caused changes typically associated with avoidance of road edges, such as changes in habitat structure and an increase in invasive or exotic species (N. Koper, personal observation) that might lead to increased predation and parasitism (Johnson and Temple 1990, Winter et al. 2000, Bollinger and Gavin 2004). It is unclear why Baird's Sparrows and Marbled Godwits avoided roads while other species did not. Results of previous research on effects of roads on grassland birds have been variable. Our results are consistent with a study comparing road edges with trail edges in Colorado: Baird's Sparrows were much less abundant near roads, indicating an avoidance of roads, whereas Clay-colored Sparrows, Horned Larks, and Western Meadowlarks were similarly abundant near roads and trails (Sutter et al. 2000). However, their results differ from ours in that Sprague's Pipits responded negatively to roads (Sutter et al. 2000), whereas pipits did not respond to roads in our study. In another study, Vesper Sparrows avoided trails (Miller et al. 1998), while in our study Vesper Sparrows were attracted to roads. Vesper Sparrows may have been attracted to road edges because of the presence of fences as perch sites, but then we would also expect Western Meadowlarks to be attracted to roads because they also sing from perches (Davis and Lanyon 2008). Other studies of bird communities have shown that roads do influence bird abundance negatively, and that roads should be an important component in conservation planning (Gutzwiller and Barrow 2003).

Because display height and resource-use strategies did not explain the responses of birds to edges in our study, other hypotheses might help explain the observed edge effects. Some of these can be tentatively rejected based on logic or the natural history of our focal species. First, increased parasitism and predation near agricultural edges is an unlikely cause because nesting success of grassland songbirds is often higher near edges in mixed-grass prairies (e.g., Davis 2004, Renfrew et al. 2005, Koper and Schmiegelow 2007). We speculate that variation in microclimate due to edge effects, e.g., increased wind penetration (Mesquita et al. 1999, Bollinger and Gavin 2004) would be restricted to an area immediately adjacent to prairie edges; therefore, this mechanism seems unlikely to explain why some species avoided edges at great distances such as Chestnut-collared Longspur avoidance of crops, at least $1.95 \mathrm{~km}$. Reduced food availability, i.e., insects, near cropland edges in mixed-grass prairies (Hickman et al. 2006) is also an unlikely mechanism because a number of ongoing studies (Selinger 2010; N. Koper, unpublished data) suggest that mixed-grass prairie songbirds do not select habitat based on food availability. Finally, it seems unlikely that passive displacement of territories (Fletcher and Koford 2003) could explain edge avoidance at the scale of many 100s of meters, as observed in our study.

Of the ten proposed mechanisms we summarized in our introduction, only two seem plausible for explaining edge avoidance or attraction by breeding birds in mixed-grass 
prairies: some species, but not others, might be influenced by a change in vegetation structure near edges; and some species may have an innate preference for certain types of habitat, including both degree of habitat fragmentation, and vegetation structure (Bollinger and Gavin 2004). The distances at which vegetation density responded to habitat edge corresponded closely with the distances at which Chestnut-collared Longspurs responded to habitat edge; for example, vegetation was more dense closer to cropland and forage habitats, increasing from the minimum by $25 \%$ at $2.0 \mathrm{~km}$ from the edge $(\mathrm{LCL}=1.59, \mathrm{UCL}=2.37$; Koper, unpublished data, 2008), consistent with the threshold at which Chestnut-collared Longspurs avoided cropland and forage habitats. There may also be more invasive plant species near edge habitats (Gelbard and Harrison 2003); although our study was not designed to evaluate abundance of invasive plants, we found few invasive species in our study areas during our vegetation structure surveys (N. Koper, personal observation). Thus, it seems unlikely invasive species had a strong influence on edge avoidance in our study. Some of our other results are qualitatively consistent with the hypothesis that responses to habitat edge may be driven by vegetation structure. For example, species preferring denser vegetation may increase in abundance near cropland edges, such as Clay-colored Sparrows or Western Meadowlarks, as we observed in our study. Nonetheless, many species that are relatively insensitive to vegetation structure, at least within the range of conditions among our study sites, still showed sensitivity to habitat edges, e.g., Sprague's pipits. Further, Horned Larks can prefer cropland habitat for foraging and nesting (Beason 1995), but they actually avoided croplands in this study. Therefore, vegetation structure alone cannot explain many of the edge effects we observed.

Species' responses to more than one edge type were usually either positive or negative, but not both, except for Savannah Sparrow. For example, the Baird's Sparrow avoided road and wetland edges, and did not respond to cropland edges, whereas Clay-colored Sparrows were attracted to cropland and wetland edges, and did not respond to road edges. This suggests that part of these species' responses to edge habitat stems from an innate preference for preferred habitat and is similar for the different edge types. We note that an innate response to habitat edges (Bollinger and Gavin 2004) is a proximate, not ultimate explanation, and acknowledge that the evolutionary reasons for selection for or against edges are not yet clear. There is insufficient data in the literature for all our focal species to evaluate whether other life-history strategies, such as longevity and site fidelity, might explain variable sensitivity to edges among species, but it is possible that these unmeasured variables might have greater explanatory power than those we were able to address.

Our analyses revealed a number of surprisingly complex nonlinear responses to edges, where abundance did not consistently increase or decrease, but instead increased and decreased at irregular distances to edge. Specifically, we could not determine if Baird's Sparrow abundance increased or decreased in response to crop edges, if Clay-colored Sparrow abundance increased or decreased in response to road edges, and if Vesper Sparrow abundance increased or decreased in response to wetland edges. Presumably, we detected these unusual patterns because we used nonlinear models, in contrast to the linear models used in most previous studies in which effects of edges on grassland birds were evaluated (e. g., Fletcher and Koford 2003, Davis 2004, Fontaine et al. 2004, Koper and Schmiegelow 2006a). Although shrub densities were very low in our study area, plots that were near shrubby patches may have been an influential factor in these complex nonlinear responses, because each of these three species responds to shrubby habitat. To verify that these species respond inconsistently to the various edge types, studies that evaluate within-edge variability, i.e., dirt vs. paved roads; row crop vs. hay field, will be required, since our study could not distinguish edges with such fine criteria.

\section{CONCLUSION}

The distances of observed edge effects on grassland birds are difficult to explain with any of the proposed mechanisms. The maximum distance of crop edge avoidance by birds, at least $1.95 \mathrm{~km}$ by Chestnut-collared Longspurs, was almost twice that reported previously for other species of grassland passerines in mixed-grass prairies (Koper et al. 2009), suggesting that habitat fragmentation and associated edge effects may greatly reduce the availability of high-quality prairie habitat for grassland birds. We did not examine possible synergistic relationships in this paper, which might exaggerate the impact of any one edge effect (Ewers and Didham 2008); synergistic or multiplicative effects of multiple mechanisms might explain why effects were detected almost $2 \mathrm{~km}$ away from edges.

Populations of most grassland species are declining, including both specialist and generalist species (Knopf 1994, Askins et al. 2007), and Sprague's Pipits and Chestnut-collared Longspurs are of federal conservation concern in Canada (COSEWIC 2010). These species both responded negatively and at large distances to crop edges. Such avoidance would result in a dramatic loss of core grassland habitat for these species (Koper et al. 2009), suggesting that less habitat is available for these species than a naive evaluation of amount of mixed-grass prairie remaining would suggest. Preventing encroachment of agriculture into native prairie is critical for the conservation of grassland birds because agricultural encroachment results in both loss of habitat and increased edge effects. There may be additional risks to grassland birds that select for edge habitat, e.g., Clay-colored Sparrows, if that habitat is laden with pollutants such as pesticides or vehicle fluids, or has increased hyperdynamism. Conversely, roads with low traffic volumes may have relatively small impacts 
on grassland birds. Our results, which demonstrate that many species of grassland birds respond negatively to edges, suggest that there have been a number of cumulative impacts of anthropogenic activities on the landscape. However, the reasons for this edge avoidance remain frustratingly cryptic. We urge further research on effects of edges on predator communities and nesting success, and on animal's perception of their environment at the landscape scale, to help identify mechanisms that might explain why grassland birds respond to edges at such large distances.

Responses to this article can be read online at:

http://www.ace-eco.org/issues/responses.php/534

\section{Acknowledgments:}

We thank all landowners and leaseholders who allowed us to conduct surveys on their lands. We thank the Eastern Irrigation District and Ducks Unlimited Canada for facilitating the field work. Many research assistants contributed to data collection. C. L. MacNevin provided GIS assistance. We thank four anonymous reviewers, G. Ritchison, and K. Hobson for their helpful editorial comments. This research was funded through the Ducks Unlimited Canada Brooks office, The North American Waterfowl Management Plan, Alberta Sport, Recreation, Parks and Wildlife Foundation, Antelope Creek Habitat Development Area, Science Horizons and Summer Career Placements (Environment Canada), Natural Sciences and Engineering Research Council, John and Patricia Schlosser Environment Scholarship, Izaak Walton Killam Memorial Scholarship, Bill Shostak Wildlife Award, Richard H.G. Bonnycastle Graduate Fellowship (Institute for Wetland and Waterfowl Research, Ducks Unlimited), Margaret (Peg) Brown Award in Environmental Studies and Wildlife Resources, Ralph Steinhauer Award, the University of Alberta Walter H. Johns Graduate Fellowship, and the Manitoba Graduate Scholarship.

\section{LITERATURE CITED}

Ahlering, M. A., D. H. Johnson, and J. Faaborg. 2009. Factors associated with arrival densities of Grasshopper Sparrow (Ammodramus savannarum) and Baird's Sparrow (A. bairdii) in the upper Great Plains. Auk 126:799-808.

Allen, J. N. 1980. The ecology and behavior of the Long-billed Curlew in southeastern Washington. Wildlife Monographs 73:6-68.

Arnold, T. W. 2010. Uninformative parameters and model selection using Akaike's Information Criterion. Journal of Wildlife Management 74:1175-1178. http://dx.doi.org/10.1111/ j.1937-2817.2010.tb01236.x
Askins, R. A., F. Chávez-Ramírez, B. C. Dale, C. A. Haas, J. R. Herkert, F. L. Knopf, and P. D. Vickery. 2007. Conservation of grassland birds in North America: understanding ecological processes in different regions. Ornithological Monographs 64:1-46.

Beason, R. C. 1995. Horned Lark (Eremophila alpestris). In A. Poole, editor. The birds of North America online. Number 195. Cornell Lab of Ornithology, Ithaca, New York, USA. [online] URL: http://bna.birds.cornell.edu/bna/species/195/ articles/introduction

Bollinger, E. K., and T. A. Gavin. 2004. Responses of nesting Bobolinks (Dolichonyx oryzivorus) to habitat edges. Auk 121:767-776.

Brittingham, M. C., and S. A. Temple. 1983. Have cowbirds caused forest songbirds to decline? BioScience 33:31-35. http://dx.doi.org/10.2307/1309241

Burnham, K. P., and D. R. Anderson. 2002. Model selection and multimodel inference: a practical information-theoretic approach. Second edition. Springer-Verlag, New York, New York, USA.

Cartwright, B. W., T. M. Shortt, and R. D. Harris. 1937. Baird's Sparrow. Contributions of the Royal Ontario Museum of Zoology, no. 11. Transactions of the Royal Canadian Institute 46:153-198.

Committee on the Status of Endangered Wildlife in Canada (COSEWIC). 2010. Candidate wildlife species. COSEWIC, Gatineau, Québec, Canada. [online] URL: http://www. cosewic.gc.ca/eng/sct3/index_e.cfm

Cunningham, M. A., and D. H. Johnson. 2006. Proximate and landscape factors influence grassland bird distributions. Ecological Applications 16:1062-1075. http://dx.doi. org/10.1890/1051-0761(2006)016[1062:PALFIG]2.0.CO;2

Davis, S. K. 2004. Area sensitivity in grassland passerines: effects of patch size, patch shape, and vegetation structure on bird abundance and occurrence in southern Saskatchewan. Auk 121:1130-1145.

Davis, S. K., R. M. Brigham, T. L. Shaffer, and P. C. James. 2006. Mixed-grass prairie passerines exhibit weak and variable responses to patch size. $A u k$ 123:807-821. http://dx. doi.org/10.1642/0004-8038(2006)123[807:MPPEWA]2.0.CO;2

Davis, S. K., D. C. Duncan, and M. Skeel. 1999. Distribution and habitat associations of three endemic grassland songbirds in southern Saskatchewan. Wilson Bulletin 111:389-396.

Davis, S. K., and W. E. Lanyon. 2008. Western Meadowlark (Sturnella neglecta). In A. Poole, editor. The birds of North America online. Number 104. Cornell Lab of Ornithology, Ithaca, New York, USA. [online] URL: http://bna.birds. cornell.edu/bna/species/104/articles/introduction 
Dechant, J. A., M. L. Sondreal, D. H. Johnson, L. D. Igl, C. M. Goldade, M. P. Nenneman, and B. R. Euliss. 2003a. Effects of management practices on grassland birds: Marbled Godwit. Northern Prairie Wildlife Research Center, Jamestown, North Dakota, USA. [online] URL: http://www. npwrc.usgs.gov/resource/literatr/grasbird/mago/mago.htm

Dechant, J. A., M. L. Sondreal, D. H. Johnson, L. D. Igl, C. M. Goldade, P. A. Rabie, and B. R. Euliss. 2003b. Effects of management practices on grassland birds: Long-billed Curlew. Northern Prairie Wildlife Research Center, Jamestown, North Dakota, USA. [online] URL: http://www. npwrc.usgs.gov/resource/literatr/grasbird/lbcu/lbcu.htm

Dodds, W. K., K. Gido, M. R. Whiles, K. M. Fritz, and W. J. Matthews. 2004. Life on the edge: the ecology of Great Plains prairie streams. BioScience 54:205-216. http://dx.doi. org/10.1641/0006-3568(2004)054[0205:LOTETE]2.0.CO;2

Dugger, B. D., and K. M. Dugger. 2002. Long-billed Curlew (Numenius americanus). In A. Poole, editor. The birds of North America online. Number 628. Cornell Lab of Ornithology, Ithaca, New York, USA. [online] URL: http://bna.birds. cornell.edu/bna/species/628/articles/introduction

Efford, M. G., and D. K. Dawson. 2009. Effect of distancerelated heterogeneity on population size estimates from point counts. Auk 126:100-111. http://dx.doi.org/10.1525/auk.2009.07197

Ewers, R. M., and R. K. Didham. 2006. Confounding factors in the detection of species responses to habitat fragmentation. Biological Reviews 81:117-142. http://dx.doi.org/10.1017/ $\underline{\text { S1464793105006949 }}$

Ewers, R. M., and R. K. Didham. 2008. Pervasive impact of large-scale edge effects on a beetle community. Proceedings of the National Academy of Sciences 105:5426-5429. http:// dx.doi.org/10.1073/pnas.0800460105

Fisher, R. J., and S. K. Davis. 2011. Habitat use by Sprague's Pipits (Anthus spragueii) in native pastures and planted, nonnative hay fields. Auk 128:273-282. http://dx.doi.org/10.1525/ $\underline{\text { auk.2011.10148 }}$

Fletcher, R. J., Jr., and R. R. Koford. 2003. Spatial responses of Bobolinks (Dolichonyx oryzivorus) near different types of edges in northern Iowa. Auk 120:799-810.

Fontaine, A. L., P. L. Kennedy, and D. H. Johnson. 2004. Effects of distance from cattle water developments on grassland birds. Journal of Range Management 57:238-242. http://dx.doi.org/10.2307/4003790

Forman, R. T. T., and L. E. Alexander. 1998. Roads and their major ecological effects. Annual Review of Ecology and Systematics 29:207-231. http://dx.doi.org/10.1146/annurev. ecolsys.29.1.207
Gates, J. E., and L. W. Gysel. 1978. Avian nest dispersion and fledging success in field-forest ecotones. Ecology 59:871-883. http://dx.doi.org/10.2307/1938540

Gelbard, J. L., and S. Harrison. 2003. Roadless habitats as refuges for native grasslands: interactions with soil, aspect, and grazing. Ecological Applications 13:404-415. http://dx. doi.org/10.1890/1051-0761(2003)013[0404:RHARFN]2.0.CO;2

Gratto-Trevor, C. L. 2000. Marbled Godwit (Limosa fedoa). In A. Poole, editor. The birds of North America online. Number 492. Cornell Lab of Ornithology, Ithaca, New York, USA. [online] URL: http://bna.birds.cornell.edu/bna/species/492/ articles/introduction

Green, M. T. 1992. Adaptations of Baird's Sparrows (Ammodramus bairdii) to grasslands: acoustic communication and nomadism. Dissertation, University of North Carolina, Chapel Hill, North Carolina, USA.

Gutzwiller, K. J., and W. C. Barrow, Jr. 2003. Influences of roads and development on bird communities in protected Chihuahuan Desert landscapes. Biological Conservation 113:225-237. http://dx.doi.org/10.1016/S0006-3207(02)00361-0

Guyn, K., and R. G. Clark. 1999. Factors affecting survival of Northern Pintail ducklings in Alberta. Condor 101:369-377. http://dx.doi.org/10.2307/1370000

Hickman, K. R., G. H. Farley, R. Channell, and J. E. Steier. 2006. Effects of old world bluestem (Bothriochloa ischaemum) on food availability and avian community composition within the mixed-grass prairie. Southwestern Naturalist 51:524-530. http://dx.doi.org/10.1894/0038-4909 (2006)51[524:EOOWBB]2.0.CO;2

Hill, D. P., and L. K. Gould. 1997. Chestnut-collared Longspur (Calcarius ornatus). In A. Poole, editor. The birds of North America online. Number 288. Cornell Lab of Ornithology, Ithaca, New York, USA. [online] URL: http://bna.birds. cornell.edu/bna/species/288/articles/introduction

Horn, D. J., M. L. Phillips, R. R. Koford, W. R. Clark, M. A. Sovada, and R. J. Greenwood. 2005. Landscape composition, patch size, and distance to edges: interactions affecting duck reproductive success. Ecological Applications 15:1367-1376. http://dx.doi.org/10.1890/03-5254

Ingelfinger, F., and S. Anderson. 2004. Passerine response to roads associated with natural gas extraction in a sagebrush steppe habitat. Western North American Naturalist 64:385-395.

Johnson, D. H. 1980. The comparison of usage and availability measurements for evaluating resource preference. Ecology 61:65-71. http://dx.doi.org/10.2307/1937156 
Johnson, D. H. 1999. Statistical considerations in monitoring birds over large areas. In R. Bonney, D. N. Pashley, R. J. Cooper, and L. Niles, editors. Strategies for bird conservation: the partners in flight planning process. Cornell Lab of Ornithology, Ithaca, New York, USA. [online] URL: http:// birds.cornell.edu/pifcapemay/johnson.htm

Johnson, D. H. 2008. In defense of indices: the case of bird surveys. Journal of Wildlife Management 72:857-868.

Johnson, R. G., and S. A. Temple. 1990. Nest predation and brood parasitism of tallgrass prairie birds. Journal of Wildlife Management 54:106-111. http://dx.doi.org/10.2307/3808909

Jones, S. L., and J. E. Cornely. 2002. Vesper Sparrow (Pooecetes gramineus). In A. Poole, editor. The birds of North America online. Number 624. Cornell Lab of Ornithology, Ithaca, New York, USA. [online] URL: http://bna.birds. cornell.edu/bna/species/624/articles/introduction

Knapton, R. W. 1994. Clay-colored Sparrow (Spizella pallida). In A. Poole, editor. The birds of North America online. Number 120. Cornell Lab of Ornithology, Ithaca, New York, USA. [online] URL: http://bna.birds.cornell.edu/bna/ species/120/articles/introduction http://dx.doi.org/10.2173/ bna. 120

Knopf, F. L. 1994. Avian assemblages on altered grasslands. Studies in Avian Biology 15:67-84.

Koper, N., and F. K. A. Schmiegelow. 2006a. Effects of habitat management for ducks on target and nontarget species. Journal of Wildlife Management 70:823-834. http://dx.doi. org/10.2193/0022-541X(2006)70[823:EOHMFD]2.0.CO;2

Koper, N., and F. K. A. Schmiegelow. 2006b. A multi-scaled analysis of avian response to habitat amount and fragmentation in the Canadian dry mixed-grass prairie. Landscape Ecology 21:1045-1059. http://dx.doi.org/10.1007/s10980-006-0004-0

Koper, N., and F. K. A. Schmiegelow. 2007. Does management for duck productivity affect songbird nesting success? Journal of Wildlife Management 71:2249-2257. http://dx.doi.org/10.2193/2006-354

Koper, N., D. J. Walker, and J. Champagne. 2009. Nonlinear effects of distance to habitat edge on Sprague's Pipits in southern Alberta, Canada. Landscape Ecology 24:1287-1297. http://dx.doi.org/10.1007/s10980-009-9375-3

Laurance, W. F. 2002. Hyperdynamism in fragmented habitats. Journal of Vegetation Science 13:595-602. http://dx. doi.org/10.1111/j.1654-1103.2002.tb02086.x

Laurance, W. F., and E. Yensen. 1991. Predicting the impacts of edge effects in fragmented habitats. Biological Conservation 55:77-92. http://dx.doi.org/10.1016/0006-3207 (91) $90006-\mathrm{U}$
Lowther, P. E. 1993. Brown-headed Cowbird (Molothrus ater). In A. Poole, editor. The birds of North America online. Number 047. Cornell Lab of Ornithology, Ithaca, New York, USA. [online] URL: http://bna.birds.cornell.edu/bna/species/047/ articles/introduction

Lowther, P. E., H. D. Douglas, III, and C. L. Gratto-Trevor. 2001. Willet (Tringa semipalmata). In A. Poole, editor. The birds of North America online. Number 579. Cornell Lab of Ornithology, Ithaca, New York, USA. [online] URL: http:// bna.birds.cornell.edu/bna/species/579/articles/introduction

Mengel, R. M. 1970. The North American central plains as an isolating agent in bird speciation. Pages 280-340 in W. Dort and J. K. Jones, editors. Pleistocene and recent environments of the central Great Plains. University of Kansas Press, Lawrence, Kansas, USA.

Mesquita, R. C. G., P. Delamônica, and W. F. Laurance. 1999. Effect of surrounding vegetation on edge-related tree mortality in Amazonian forest fragments. Biological Conservation 91:129-134. http://dx.doi.org/10.1016/S0006-3207(99)00086-5

Miller, S. G., R. L. Knight, and C. K. Miller. 1998. Influence of recreational trails on breeding bird communities. Ecological Applications 8:162-169. http://dx.doi.org/10.1890/1051-0761 (1998)008[0162:IORTOB]2.0.CO;2

Nowicki, T. 1973. A behavioral study of the Marbled Godwit in North Dakota. Thesis. Central Michigan University, Mount Pleasant, Michigan, USA.

Quinn, G. P., and M. J. Keough. 2002. Experimental design and data analysis for biologists. Cambridge University Press, New York, New York, USA. http://dx.doi.org/10.1017/ CBO9780511806384

R Core Team. 2012. R: A language and environment for statistical computing. R Foundation for Statistical Computing, Vienna, Austria.

Renfrew, R. B., C. A. Ribic, and J. L. Nack. 2005. Edge avoidance by nesting grassland birds: a futile strategy in a fragmented landscape. Auk 122:618-636. http://dx.doi. org/10.1642/0004-8038(2005)122[0618:EABNGB]2.0.CO;2

Robbins, M. B. 1998. Display behavior of male Sprague's Pipits. Wilson Bulletin 110:435-438.

Robbins, M. B., and B. C. Dale. 1999. Sprague's Pipit (Anthus spragueii). In A. Poole, editor. The birds of North America online. Number 439. Cornell Lab of Ornithology, Ithaca, New York, USA. [online] URL: http://bna.birds.cornell.edu/bna/ species/439/articles/introduction

Ryan, M. R., and R. B. Renken. 1987. Habitat use by breeding Willets in the northern Great Plains. Wilson Bulletin 99:175-189. 
Samson, F., and F. Knopf. 1994. Prairie conservation in North America. BioScience 44:418-421. http://dx.doi.org/10.2307/1312365

SAS Institute, Inc. 2008. SAS 9.2, SAS Institute Inc., Cary, North Carolina, USA.

Selinger, A. 2010. Effects of cattle grazing on the food abundance of prairie bird species in Grasslands National Park, Saskatchewan. Thesis. University of Manitoba, Winnipeg, Manitoba, Canada.

Sheppard, S. C., M. I. Sheppard, B. Sanipelli, M. O. Gallerand, and J. Long. 2005. Ecotoxicological probable-no-effect concentrations for elements related to nuclear waste. Australasian Journal of Ecotoxicology 11:115-136.

Slud, E. V., D. P. Byar, and S. B. Green. 1984. A comparison of reflected versus test-based confidence intervals for the median survival time, based on censored data. Biometrics 40:587-600. http://dx.doi.org/10.2307/2530903

Sutter, G. C., S. K. Davis, and D. C. Duncan. 2000. Grassland songbird abundance along roads and trails in southern Saskatchewan. Journal of Field Ornithology 71:110-116.

U.S. Fish and Wildlife Service. 2008. Birds of conservation concern 2008. United States Department of Interior, Fish and Wildlife Service, Division of Migratory Bird Management, Arlington, Virginia, USA. [online] URL: http://www.fws. gov/migratorybirds/.

Vickery, P. D., P. L. Tubaro, J. M. Cardoso da Silva, B. G. Peterjohn, J. R. Herkert, and R. B. Cavalcanti. 1999. Conservation of grassland birds in the Western hemisphere. Studies in Avian Biology 19:2-26.

Wells, J. V., and P. D. Vickery. 1994. Extended flight-songs of Vesper Sparrows. Wilson Bulletin 106:696-702.

Wheelwright, N. T., and J. D. Rising. 2008. Savannah Sparrow (Passerculus sandwichensis). In A. Poole, editor. The birds of North America online. Number 045. Cornell Lab of Ornithology, Ithaca, New York, USA. [online] URL: http:// bna.birds.cornell.edu/bna/species/045/articles/introduction

Winter, M., D. H. Johnson, and J. Faaborg. 2000. Evidence for edge effects on multiple levels in tallgrass prairie. Condor 102:256-266. 